\title{
ROMAN MINING IN HISPANIA SEGOBRIGA AND THE EXPLOITATION OF LAPIS SPECULARIS
}

\section{INTRODUCTION}

In the vicinity of the ancient Roman city of Segobriga, evidence of significant mining activity during Roman times has been found, especially linked to the exploitation of lapis specularis, a material in high demand for construction purposes. It is a type of crystallized plaster that is naturally found in high concentrations. Due to its composition, it is easily exfoliable and large flakes can be obtained that can reach two meters in length.

This mining industry reached its peak between the 1 st and 2 nd centuries AD. In Hispania it stood out for its quality and exceptional qualities. Its commercialization produced great benefits and great prosperity in those areas where it was exploited and, in many cases, served as an element to strengthen their Romanization. In cities like Segobriga, the urban and economic development derived from the exploitation of this material mainly favored their local elites.

\section{ROMAN MINING IN HISPANIA}

The extraction of various metals such as gold, silver and copper, as well as other minerals such as marbles or gypsum, constituted one of the most important industries of the Roman period, which had a prominent role in the economic and urban development of many regions. As a result of its territorial expansion, Rome managed to seize huge and varied mineral resources, and its interest in them even motivated military actions for its control. In many cases, these mining operations were already active, and in others it was the Romans who began to exploit them on a large scale following a thorough global planning of the resources of the territory under their control. They always kept very present the preservation of resources in the Italian Peninsula, as well as the monetary minting policy of each momento (Mangas and Orejas, 1999, 210).

The management and exploitation of mining resources changed according to the time and places where it was developed. On occasions, the Roman State, through a procurator metallorum, was in charge of exploiting them, as happened with the 
important gold mines in the northwest of Hispania. However, in most cases, the state granted exploitation concessions to individuals, local communities or societates publicanorum, especially during the Republican era ${ }^{1}$. Salaried laborers, settlers or slaves condemned to work in them as punishment (damnati ad metalla) were employed to work in the mines. The discovery of the Lex Vipasca ${ }^{2}$ in the Portuguese town of Aljustrel, constitute one of the most complete sources for the knowledge of the Roman Law in force in Hispania. These bronzes detail the organization of the mining operations within the mining district (metalla) of Vipasca (Domergue, 1983).

The most valued minerals were exported over a long distance, such as marble and its different varieties ${ }^{3}$, which arrived in large quantities at the most important Roman ports thanks to a developed and planned commercial structure (De Nuccio and Ungaro, 2003). During the government of Augustus (27 BC - AD 14) guidelines were established for a more rational exploitation of the gold mines of the Hispanic northwest, which reached their highest productivity in the time of Vespasian (AD 69-79), reaching up to 20,000 annual pounds of gold estimated to be worth about 90 million sesterces. After the conquest and pacification of that area of Hispania, important gold veins were found north of the Douro, such as Trêsminas and Campo de Jales in Portugal, as well as Las Medulas in Spain, which is a magnificent example of a mining operation from Roman times.

Silver was another highly valued mineral resource, and during the Republic it was the Hispanic metal par excellence due to its abundance. From the Baebelo mines, located in the vicinity of Carthago Nova, up to 300 pounds of silver were extracted per day. The silver richness of Hispania was such that it was possible to find native silver ores (completely depleted today in the Iberian Peninsula), although it used to be found

\footnotetext{
${ }^{1}$ In his work Publicans and Sinner (Oxford, 1972), E. Badian hypothesizes that during the Republic, practically all the Hispanic mines were exploited exclusively by large societates plublicanorum.

2 They are two bronze tablets from the 2nd century AD that include the legislation applied to the exploitation of the mines of the Vipasca district. The first of them was found in 1876, and deals with the rights of the tenants of the mines. The second, found in 1906, deals with the legal regulation of mining concessions and establishes a series of technical standards for their exploitation.

${ }^{3}$ The most appreciated marbles in Roman times were the varieties known as red porphyry, giallo antico and pavonazzetto.
} 
together with other minerals such as lead ${ }^{4}$, copper ${ }^{5}$ or mercury ${ }^{6}$, as well as gold. In addition to these two metals, the Romans also obtained from Hispania other minerals of different economic interest, such as cinnabar from the Sisapo area (Ciudad Real province), to obtain lead and mercury, used for the amalgamation of gold when it did not appear in pure natural state.

Copper was also highly valued, being used in metalwork, either in its pure state or mixed with other metals, to obtain the industrial alloy par excellence of the time, bronze.

\section{BRIEF HISTORY OF SEGOBRIGA}

The remains of Segobriga are found in the Segobriga Archaeological Park, within the municipality of Saelices, in the province of Cuenca (Spain).

Despite the city is completely in ruins, its excellent state of conservation compared to other sites of similar characteristics in the Iberian Peninsula, caused it to be classified as a National Monument on June 3,1931 by the Spanish republican government of Niceto Alcalá Zamora.

The name Segobriga denotes clear Celtiberian origins, and probably in its beginnings it was a Celtiberian oppidum located in what would later be the northern part of the Roman city, whose location in the vicinity of the Cigüela river served to protect it. Although no remains have been found that confirm the presence of the aforementioned oppidum, the finding of a fragment of Attic pottery, dating from the 5th century BC, seems to confirm the occupation of that place at that time.

Strabo (64 BC- AD 24) is the first author to provide the first references to Segobriga, by mentioning it briefly (Strabo, Geo. III, 4.13) in relation to the confrontation between

\footnotetext{
${ }^{4}$ Known as argentiferous galena. Galena is a type of lead sulfide that in its composition can contain traces of other minerals such as silver, sometimes reaching up to $1 \%$ of its content. In its natural state it is possible to find it forming crystals, or solid.

5 It is a sulfur composed, for the most part, of sulfur and iron and is widely used to obtain sulfuric acid. It was commonly called "fool's gold" because of its great resemblance to that metal. It is very abundant in the mountains of Huelva and in the Portuguese Alemtejo.

${ }^{6}$ It is known as cinnabar. It is a sulfurous compound made up, for the most part, of mercury and some sulfur. In its natural state, trigonal crystals appear next to volcanic rocks.
} 
Quintus Caecilius Metellus Pius ${ }^{7}$ and Quintus Sertorius ${ }^{8}$ during the Sertorian War (80$72 \mathrm{BC})$. As a result of this conflict, the Celtiberian Segobriga ${ }^{9}$ was destroyed, and the Roman Segobriga was erected on its remains.

Sextus Julius Frontinus (40-103), Roman politician of the 1st century AD and author of a military treatise entitled Strategemata, as well as a report called De aquaeductu, which deals with the aqueducts that supplied water to the city of Rome, states that Segobriga was attacked by Viriatus around $146 \mathrm{BC}$ due to the alliance that this still Celtiberian city had sealed with Rome (Frontinus, Strat. III, 11,4). The one who provides the greatest amount of data on Segobriga is Pliny the Elder (AD 23-79) in his Naturalis Historia, who calls the city "caput Celtiberiae", integrated into the Caesaraugustan conventus iuridicus ${ }^{10}$ as a stipendiary city (Pliny, Naturalis Historia III, $3.25)$.

Around 12 BC Segobriga was considered a municipium, which led to greater urban and economic development due to an ambitious monumental urban project that concluded around AD 80 under the Flavian dynasty. Segobriga was one of the few Roman cities in Hispania that enjoyed the privilege of issuing currency, as it was a place characterized by an outstanding commercial activity, mainly related to the exploitation of lapis specularis, which attracted people from various parts of the Empire. This has been confirmed by the discovery of numerous inscriptions in Segobriga itself. Due to the vigorous mining and commercial activity present in Segobriga, and to facilitate the transportation and commercialization of lapis specularis, the city was well connected with other important Hispanic nuclei and mining districts, such as Carthago Nova.

\footnotetext{
${ }^{7}$ (130-64 BC) Republican politician and military man who participated in the Sertorius War on the side of the optimates, facing off against Gaius Marius and his allies. He managed to defeat Quintus Sertorius in Hispania.

8 (122-72 BC) Roman military and political leader known for his opposition to the interests of Lucius Cornelius Cinna from Hispania, where the confrontation with some of his supporters would take place.

${ }^{9}$ The Olcades, a tribe of possible Celtiberian origin, occupied the lands of the current Spanish province of Cuenca and inhabited Segobriga.

${ }^{10}$ Administrative subdivision of Hispania Tarraconensis that included a good part of present-day Aragon and the Ebro valley, whose most important city was Caesaraugusta (present-day Zaragoza).
} 
According to archaeological evidence, from the 3rd century AD Segobriga's decline began, becoming more pronounced throughout the following century due to ruralization and the lower demand for lapis specularis, which ended up being replaced by glass.

\section{USES OF LAPIS SPECULARIS}

Due to its characteristics, lapis specularis was widely demanded as glazing and to allow natural lighting of interior spaces, while isolating these from the elements and environmental noises, in addition to allowing visibility towards the outside. For this, pieces of lapis specularis were conveniently adapted for insertion in racks, generally made of wood but also in ceramic, used to cover openings of varying size. Before the massive use of lapis specularis, Roman architects had used other materials such as other minerals or even animal skins or bladders, but none of them had its properties. It was also used for greenhouses, due to its insulating properties and translucency.

In addition to glazing, lapis specularis was used to obtain plaster with which to make moldings or plaster walls, as well as for stucco or make decorative figures intended to be placed on the facades and cornices of buildings. According to Pliny the Elder, the best plaster came from the dehydration of flakes of lapis specularis (Pliny, Naturalis Historia, XXXVI, 182), and if it was heated to charring it, it was possible to obtain "forge plaster", a binder widely used for coatings. It was also used for ornamental purposes as a cladding for certain significant buildings or surfaces, and its use in chips to cover the arena of the Circus Maximus during the celebration of some shows (Pliny, Naturalis Historia, XXXVI, 162).

\section{LAPIS SPECULARIS FROM HISPANIA}

Pliny the Elder affirmed that the best lapis specularis was obtained in Hispania, highlighting the obtained around "one hundred thousand steps ${ }^{11}$ " from the city of Segóbriga (Pliny, Naturalis Historia, XXXVI, 160).

Although in other places of the Empire there were also exploitations of lapis specularis, such as in Cyprus, Cappadocia or Sicily, none of them reached the excellence and prestige of the Hispanic, which was considered an important strategic resource of great

\footnotetext{
${ }^{11}$ A Roman passus is approximately 1.47 meters long, so the distance indicated by Pliny is 147 kilometers.
} 
commercial value that was mainly destined for export. This caused, especially at the end of the Republic and at the beginning of the Empire, the construction of new roads by the Roman State, by individuals or by companies that exploited and managed the mines under a concession regime to facilitate their transport to the ports, where it was shipped to other parts of the Empire.

Despite the great importance and intense exploitation of the lapis specularis mines, it is difficult to find archaeological remains outside their main areas of exploitation, and if they exist they are testimonial, even in those places closely related to this activity. Among the possible reasons is the fragility and composition of the lapis specularis, in addition to its tendency to reintegrate itself back into the environment over time, which has made it go unnoticed at times and not be considered an archaeological remains.

\section{LAPIS SPECULARIS MINING IN SEGOBRIGA}

The lapis specularis mines in the Segobriga area used to be managed directly by the Roman treasury, while the city was in charge of organizing the work. There were times when some of them were transferred under concession to individuals or companies, the most common being the leasing of mining shafts.

Before any mining work, it was essential to locate where the deposits of lapis specularis were located. Roman prospectors were usually aided by the inhabitants of the area to carry out this task. Once found, ramp entrances were made, although the most common were mining shafts that communicated the mining complex and its different levels of exploitation, in addition to providing light and air. Mining shafts used to be quadrangular or rectangular due to the facilities that these forms provided in the event that the ground had to be secured by means of wooden shoring in order to avoid collapses. In those mining shafts that had been dug into the rock, shoring was not necessary. The average depth of the mining shafts ranged between 20 and 30 meters, while their diameter was between 2 and 2.5 meters. Small incisions were made in the walls of the mining shafts that were used as handles to facilitate the ascent and descent through them. The distance between the mining shafts was small, in order to allow simultaneous work in different places of the mining operation. 
The interior was structured in several rooms, from which galleries were dug in different directions. This distribution system was widely used during Antiquity in the so-called "indoor mining".

Oil lights were used to illuminate the interior of the mines, arranged at regular intervals in small holes in the walls, although sometimes torches were used. Chisels, hammers or pickaxes were used as tools, especially those made of metal. Stakes were used to open new galleries or rooms, also used to sculpt steps that, in some points, facilitated access to certain places, as well as to make holes in the walls that would be used to install pulleys, winches or anchors. Before extracting the lapis specularis, and after having been cut with saws to the desired size and shape, the blocks were driven through the galleries to the shafts, from where they were lifted by pulleys and winches arranged outside, although they could also be taken down the ramps with animals.

Once extracted, the lapis specularis blocks were roughened and selected according to their quality and size. Later they were again cut into square or rectangular pieces for better storage and transport, although possibly, and due to customer requirements, they were cut into other shapes.

\section{CONCLUSION}

Briefly, it could be stated that, in Segobriga, the exploitation and commercialization of the lapis specularis constituted an outstanding, if not essential, vehicle for its urban and economic development thanks to the great demand and appreciation for this element. In addition, the intense mining activity helped the development and emergence of other industries, which further enhanced the economic dynamism of the city.

That prosperity attracted people from all over the Empire, highlighting those from the Italian Peninsula, who managed to control, together with the autochthonous elites, the exploitation and commercialization of the lapis specularis. Their enrichment allowed them to be part of the Segobriga elite and access their magistrates and sociopolitical and economic control of the area. 


\section{BIBLIOGRAPHY AND INTERNET SOURCES}

- ALFÖLDY, G. - SPAIN, in BOWMAN, A.K.; GARNSEY, P.; RATHBONE, D. (eds.) The Cambridge Ancient History (vol. XI), Cambridge University Press, Cambridge (2000) Pp. 448-452

- BERNÁRDEZ GÓMEZ, M.J.; GUISADO DI MONTI, J.C. - La minería romana del lapis especularis. Una minería de interior, in ABAD CASAL, L. (et al.) Investigaciones Arqueológicas en Castilla-La Mancha 1996-2002, Junta de Comunidades de Castilla-La Mancha, Servicio de Publicaciones, Toledo (2003) Pp. 245-256

- FERNÁNDEZ URIEL, P.; MAÑAS ROMERO, I. - La Civilización Romana, UNED, Madrid (2013) Pp. 246-248

- GOZAlBes CRAVIOTO, E. - Caput Celtiberiae. La tierra de Cuenca en las fuentes clásicas, Ediciones de la Universidad de Castilla-La Mancha, Cuenca (2000)

- LEVEAU, P. - The Western Provinces, in SCHEIDEL, W.; MORRIS, I.; SALLER, R. (eds) The Cambridge Economic History of the Greco-Roman World, Cambridge University Press, Cambridge (2007) Pp. 659-660

- SÁNCHEZ MORENO, E. (coord.); GÓMEZ PANTOJA, J.L. - Protohistoria y Antigüedad de la Península Ibérica vol.II (La Iberia prerromana y la Romanidad), Sílex, Madrid (2008) Pp. 555-563

- SAYAS ABENGOCHEA, J.J. - Historia antigua de la Península Ibérica, UNED, Madrid (2003) Pp. 290-291

- Diccionari de geología - Institut d'Estudis Catalans http://cit.iec.cat/dgeol/default.asp?opcio=0 (accessed June 2021)

- Parque Arqueológico de Segóbriga: https://cultura.castillalamancha.es/patrimonio/parques-arqueologicos/segobriga/ (accessed May 2021) 